\title{
Direct measurement of ozone production rates in Houston in 2009 and comparison with two estimation methods
}

\author{
M. Cazorla ${ }^{1, *}$, W. H. Brune ${ }^{1}$, X. Ren ${ }^{2, * *}$, and B. Lefer ${ }^{3}$ \\ ${ }^{1}$ Department of Meteorology, Pennsylvania State University, University Park, PA, USA \\ ${ }^{2}$ Rosenstiel School of Marine and Atmospheric Science, University of Miami, FL, USA \\ ${ }^{3}$ Department of Earth and Atmospheric Sciences, University of Houston, Houston, TX, USA \\ * now at: Atmospheric Chemistry and Dynamics Laboratory, NASA Goddard Space Flight Center, Greenbelt, MD, USA \\ ** now at: Air Resources Laboratory, National Oceanic and Atmospheric Administration, Silver Spring, MD, USA
}

Correspondence to: M. Cazorla (cazorla.chem@gmail.com)

Received: 22 September 2011 - Published in Atmos. Chem. Phys. Discuss.: 10 October 2011

Revised: 3 January 2012 - Accepted: 19 January 2012 - Published: 30 January 2012

\begin{abstract}
Net ozone production rates, $P\left(\mathrm{O}_{3}\right)$, were measured directly using the Penn State Measurement of Ozone Production Sensor (MOPS) during the Study of Houston Atmospheric Radical Precursors (SHARP, 2009). Measured $P\left(\mathrm{O}_{3}\right)$ peaked in the late morning, with values between $15 \mathrm{ppbv} \mathrm{h}^{-1}$ and $100 \mathrm{ppbv} \mathrm{h}^{-1}$, although values of 40 $80 \mathrm{ppbv} \mathrm{h}^{-1}$ were typical for higher ozone days. These measurements were compared against ozone production rates calculated using measurements of hydroperoxyl $\left(\mathrm{HO}_{2}\right)$, hydroxyl $(\mathrm{OH})$, and nitric oxide $(\mathrm{NO})$ radicals, called "calculated $P\left(\mathrm{O}_{3}\right)$ ". The same comparison was done using modeled radicals obtained from a box model with the RACM2 mechanism, called "modeled $P\left(\mathrm{O}_{3}\right)$ ". Measured and calculated $P\left(\mathrm{O}_{3}\right)$ had similar peak values but the calculated $P\left(\mathrm{O}_{3}\right)$ tended to peak earlier in the morning when $\mathrm{NO}$ values were higher. Measured and modeled $P\left(\mathrm{O}_{3}\right)$ had a similar dependence on NO, but the modeled $P\left(\mathrm{O}_{3}\right)$ was only half the measured $P\left(\mathrm{O}_{3}\right)$. The modeled $P\left(\mathrm{O}_{3}\right)$ is less than the calculated $P\left(\mathrm{O}_{3}\right)$ because the modeled $\mathrm{HO}_{2}$ is less than the measured $\mathrm{HO}_{2}$. While statistical analyses are not conclusive regarding the comparison between MOPS measurements and the two estimation methods, the calculated $P\left(\mathrm{O}_{3}\right)$ with measured $\mathrm{HO}_{2}$ produces peak values similar to the measured $P\left(\mathrm{O}_{3}\right)$ when ozone is high. Although the MOPS is new and more testing is required to verify its observations, the measurements in the SHARP field campaign show the potential of this new technique for contributing to the understanding of ozone-producing chemistry and to the monitoring of ozone's response to future air quality regulatory actions.
\end{abstract}

\section{Introduction}

Ozone pollution damages human health (Ho et al., 2007) as well as crops and forests (Madden and Hogswett, 2001). A growing body of evidence indicates that these harmful effects occur at even lower ozone levels than previously thought. In response, governmental regulatory agencies are considering reductions in the primary and secondary Ambient Air Quality Standards for ozone. For example, a reduction in the primary standard from $75 \mathrm{ppbv}$ to a new level between $60-70 \mathrm{ppbv}$ has been recently proposed (US EPA, 2010), although consideration of this new ozone standard has been delayed until 2013. The current number of counties nationwide in nonattainment (342) would increase by $50 \%$ with a new standard set at 70 ppbv. This increase would be $90 \%$ if the standard were set at $60 \mathrm{ppbv}$ (McCarthy, 2010). Hence, attaining these ozone standards is a challenge for air quality managers.

Areas designated as being in non-attainment with the present ozone standard, such as Houston-GalvestonBrazoria, would face a more difficult challenge under new rules. As an example, during the month of May 2009, the Texas Commission on Environmental Quality (2011) reported four cases of exceedances of the current primary ozone standard in Houston. Thus, developing economically viable reduction policies will require more exigent controls on mobile and point sources of the ozone precursors, nitrogen oxides $\left(\mathrm{NO}_{\mathrm{x}}=\mathrm{NO}+\mathrm{NO}_{2}\right)$ and volatile organic compounds (VOCs). Determining the effectiveness of these new policies could benefit from new monitoring strategies that include measurements of not only ambient ozone but also the actual ozone production rate. 
Ambient ozone is the result of local photochemical production, surface deposition, and transport processes, as given in the ozone budget equation (Eq. 1):

$\frac{\partial\left[\mathrm{O}_{3}\right]}{\partial t}=P\left(\mathrm{O}_{3}\right)-\frac{u_{\mathrm{d}}}{H}\left[\mathrm{O}_{3}\right]-\boldsymbol{v} \cdot \nabla\left[\mathrm{O}_{3}\right]$

In Eq. (1), the time-rate-of-change of measured ambient $\mathrm{O}_{3}$ is on the left-hand side of the equation, $P\left(\mathrm{O}_{3}\right)$ is the instantaneous net chemical ozone production rate, $u_{\mathrm{d}}$ is the ozone deposition velocity, $H$ is the mixed layer height, and $v$ is the wind velocity. The amount of ground-level ozone and its time-rate-of-change can be obtained from a direct measurement using a commercial ozone analyzer. These ambient ozone measurements, however, do not indicate whether ozone is produced locally or advected from other areas. Thus, the relationship between ozone and its precursors cannot be obtained from simple ambient ozone measurements. Typically, ozone is linked to its precursors using air quality models that include $\mathrm{NO}_{\mathrm{x}}$ and VOC emissions, the photochemistry that produces ozone, and the meteorology that drives ozone transport. The emissions inventories and transport needed by the models are both uncertain (Fox, 1984; NRC, 1991; Gilliland et al., 2008). This factor complicates the ability for the models to test the effectiveness of emissions reductions on ozone production.

The chemistry of tropospheric ozone production has been presented by several authors (Haagen-Smit et al., 1953; Finlayson-Pitts and Pitts, 1977; Logan et al., 1981; Gery et al., 1989; Kleinman, 2005; Seinfeld and Pandis, 2006). The current understanding of the ozone-forming chemistry in the troposphere indicates that the photolysis of nitrogen dioxide $\left(\mathrm{NO}_{2}\right)$ is the only known source of ozone in the daytime. In the absence of hydroperoxyl radical $\left(\mathrm{HO}_{2}\right)$ and organic peroxy radicals $\left(\mathrm{RO}_{2}\right)$, nitric oxide $(\mathrm{NO})$, nitrogen dioxide $\left(\mathrm{NO}_{2}\right)$ and ozone $\left(\mathrm{O}_{3}\right)$ achieve photosteady state (PSS) and no new ozone is formed. New ozone is formed via reactions of peroxy radicals $\left(\mathrm{HO}_{2}+\mathrm{RO}_{2}\right)$ and $\mathrm{NO}$ to make $\mathrm{NO}_{2}$. Solar ultraviolet light dissociates $\mathrm{NO}_{2}$ into $\mathrm{NO}$ and $\mathrm{O}$, with $\mathrm{O}$ rapidly reacting with $\mathrm{O}_{2}$ to make ozone. Peroxy radicals come from reaction sequences that continuously cycle $\mathrm{OH}$, $\mathrm{HO}_{2}$, and $\mathrm{RO}_{2}$ radicals; these sequences are fast enough that the steady state of the $\mathrm{HO}_{\mathrm{x}}\left(\mathrm{OH}+\mathrm{HO}_{2}\right)$ species can be assumed. The estimation of the rate of net ozone production, $P\left(\mathrm{O}_{3}\right)$, from measurements requires the knowledge of the abundance of peroxy radicals and NO present in the ambient air.

The instantaneous production of ozone in the troposphere can be represented by the kinetic rate equations:

$$
\begin{aligned}
p\left(\mathrm{O}_{3}\right)= & k_{\mathrm{HO}_{2}+\mathrm{NO}}\left[\mathrm{HO}_{2}\right][\mathrm{NO}]+\Sigma k_{\mathrm{RO}_{2 i}+\mathrm{NO}}\left[\mathrm{RO}_{2 i}\right][\mathrm{NO}] \\
l\left(\mathrm{O}_{3}\right)= & k{ }_{\mathrm{OH}+\mathrm{NO}_{2}+M}[\mathrm{OH}]\left[\mathrm{NO}_{2}\right][M]+k_{\mathrm{HO}_{2}+\mathrm{O}_{3}}\left[\mathrm{HO}_{2}\right]\left[\mathrm{O}_{3}\right] \\
& +P\left(\mathrm{RONO}_{2}\right)
\end{aligned}
$$

$P\left(\mathrm{O}_{3}\right)=p\left(\mathrm{O}_{3}\right)-l\left(\mathrm{O}_{3}\right)$

Equation (2) summarizes the production of $\mathrm{NO}_{2}$. The $k$ terms are the reaction rate coefficients and the terms in brackets are the concentration of chemical species. The two terms on the right-hand side of Eq. (2) indicate production of $\mathrm{NO}_{2}$, and therefore of ozone, from peroxy radicals reacting with NO. The terms of Eq. (3) corresponds to the reaction of $\mathrm{OH}$ and $\mathrm{NO}_{2}$ to form nitric acid, the reaction of $\mathrm{HO}_{2}$ with $\mathrm{O}_{3}$, and finally the formation of organic radicals $\mathrm{RONO}_{2}$. Equation (3) represents the reactions that reduce the ozone production rate, either by direct ozone loss or by shifting the $\mathrm{NO}_{2}$ that is in steady-state balance with ozone into reservoir species. The instantaneous net production of ozone is the difference between chemical ozone production and chemical removal, as shown by Eq. (4).

The calculation of the ozone production rate has been traditionally done by chemical modeling. In this study, we use the Regional Atmospheric Chemistry Mechanism Version 2, or RACM2, (Goliff and Stockwell, 2008, 2012). Past studies have found that ozone production rates calculated from measured radicals were greater than those calculated from modeled radicals (Martinez et al., 2003; Ren et al., 2003; Ren et al., 2004; Shirley et al., 2006; Kanaya et al., 2007). These differences have been attributed to modeled $\mathrm{HO}_{2}$ being less than measured $\mathrm{HO}_{2}$. Recent studies by Hofzumahaus et al. (2009) suggest a mechanism for the production of $\mathrm{OH}$ that maintains the ratio $\mathrm{HO}_{2} / \mathrm{OH}$ and does not involve the reaction of $\mathrm{HO}_{2}$ with $\mathrm{NO}$ and, therefore, does not result in the production of ozone at low NO levels. Although the conditions for the present study are different from those in Hofzumahaus et al. (2009), the hypothesis by Hofzumahaus et al. is an example of a mechanism that is not included in the traditional models and calculations. Monitoring the ozone production rate in real time could help identify additional mechanisms or confirm the chemistry included in the models.

The Measurement of Ozone Production Sensor (MOPS) (Cazorla and Brune, 2010) measures $P\left(\mathrm{O}_{3}\right)$. This term in the ozone budget equation (Eq. 1) is the only term that is directly affected by $\mathrm{NO}_{\mathrm{x}}$ and VOC emissions and their photochemistry. All other terms are proportional to ozone or its gradient, so that as measured $P\left(\mathrm{O}_{3}\right)$ decreases, so should ambient ozone, provided it is being produced locally and not advected from other regions. Thus, $P\left(\mathrm{O}_{3}\right)$ measurements can be used to quantify local production versus transport by comparing the rate-of-change in ambient ozone against $P\left(\mathrm{O}_{3}\right)$, especially if a network of these instruments is located along the path of meteorological features associated with ozone advection. $P\left(\mathrm{O}_{3}\right)$ measurements also provide a test of the ozone production rates that are calculated from Eq. (4) using either modeled chemical species or species measured during intensive field campaigns. Further, adding $\mathrm{NO}_{\mathrm{x}}$ or VOCs to ambient air sampled by the MOPS directly tests the sensitivity of ozone production to $\mathrm{NO}_{\mathrm{x}}$ or VOCs. Hence, MOPS 
has the potential to contribute significantly to improving the monitoring of ozone and its response to changes in $\mathrm{NO}_{\mathrm{x}}$ and VOC emissions.

The direct measurement of ambient ozone production rate was first proposed about forty years ago (Jeffries, 1971), but we independently developed a technique using an improved understanding of the photochemistry and better materials and methods that were not available then. These improvements have made a quantitative direct ambient measurement feasible.

This paper presents the first $P\left(\mathrm{O}_{3}\right)$ measurements using the MOPS, a new, relatively untested, yet promising technique. These measurements were made during an intensive field campaign in Houston in 2009 in which environmental parameters and many atmospheric constituents including radicals were measured. As a result, the MOPS $P\left(\mathrm{O}_{3}\right)$ data were compared to the ozone production rates calculated using Eq. (4) with both measured and modeled $\mathrm{HO}_{2}, \mathrm{NO}$, and $\mathrm{OH}$ radicals.

\section{Experimental methods}

\subsection{Measured $P\left(O_{3}\right)$ and description of the SHARP campaign}

The sampling site for the Study of Houston Atmospheric Radical Precursors, SHARP 2009, was the roof of Moody Tower North located at University of Houston, $70 \mathrm{~m}$ above the ground level and $5 \mathrm{~km}$ south of downtown Houston. An extensive suite of atmospheric chemical species and meteorological parameters were measured. The measurements used for this study are described below; a more detailed description of the measurements and their uncertainties are presented in Chen et al. (2010).

The Penn State MOPS (Cazorla and Brune, 2010) was deployed during the SHARP campaign between 15 April and 31 May 2009. The MOPS measures $P\left(\mathrm{O}_{3}\right)$ by finding the differential ozone between a transparent chamber (sample) and a chamber covered with a UV-blocking film (reference) that continuously sample ambient air and are exposed to the sun. Since sunlight below $400 \mathrm{~nm}$ is blocked in the reference chamber, the production of $\mathrm{OH}$ and $\mathrm{HO}_{2}$ radicals is restricted while the $\mathrm{NO}-\mathrm{NO}_{2}-\mathrm{O}_{3}$ PSS shifts towards $\mathrm{NO}_{2}$. In contrast, the clear sample chamber contains the PSS plus radical production, and consequently non-PSS $\mathrm{NO}_{2}$ that leads to the production of "new ozone". By finding the difference in the total $\mathrm{NO}_{2}+\mathrm{O}_{3}$ between the two chambers, the PSS is cancelled out and the new ozone related to the chamber exposure time yields the real time $P\left(\mathrm{O}_{3}\right)$. An $\mathrm{NO}_{2}$-to- $\mathrm{O}_{3}$ converter between the chambers and the ozone monitor accounts for the differences in PSS between the sample and reference chambers by converting $\mathrm{NO}_{2}$ to $\mathrm{O}_{3}$, so that the sum of $\mathrm{NO}_{2}$ and $\mathrm{O}_{3}$ is measured as $\mathrm{O}_{3}$. The estimated uncertainty of the MOPS is $30 \%$ at the $2 \sigma$ confidence level and 10-min integration time, although longer operation of this new technique will be needed to truly understand the uncertainties and possible interferences. A complete description of the instrument can be found in Cazorla and Brune (2010). MOPS data is available for 20 days out of the 42-day intensive SHARP study.

$\mathrm{OH}$ and $\mathrm{HO}_{2}$ radicals were measured by the Ground-based Tropospheric Hydrogen Oxides Sensor, GTHOS. The instrument and its calibration have been described in detail in Faloona et al. (2004); an abbreviated description is given here. The detection technique uses laser-induced fluorescence (LIF) at low pressure, often called FAGE (Hard et al., 1984). Ambient air is pulled into a low-pressure chamber with a vacuum pump. As the air flows through the detection chamber, $\mathrm{OH}$ radicals are excited by the laser and their resultant fluorescence is detected at a wavelength near $308 \mathrm{~nm}$. $\mathrm{HO}_{2}$ is chemically converted to $\mathrm{OH}$ by the reaction with reagent $\mathrm{NO}$ followed by LIF detection of $\mathrm{OH}$ in a second detection axis. The detection limits are about 0.02 parts per trillion by volume (pptv) for $\mathrm{OH}$ for a 20-minute integration time and $0.1 \mathrm{pptv}$ for $\mathrm{HO}_{2}$ with a $2 \sigma$ confidence level and 1-min integration time. Estimated absolute uncertainty at the $2 \sigma$ confidence level is $\pm 32 \%$ for both $\mathrm{OH}$ and $\mathrm{HO}_{2}$ (Faloona et al., 2004).

Ambient ozone (2.2\% uncertainty), $\mathrm{NO}$ and $\mathrm{NO}_{2}(5.7 \%$ uncertainty), $\mathrm{SO}_{2}$ and $\mathrm{CO}$ (5.5\% uncertainty), meteorological data and photolysis rate coefficients (less than $12 \%$ uncertainty) were monitored by the University of Houston (Lefer et al., 2010) on a tower about six meters away from the MOPS. NO and $\mathrm{NO}_{2}$ were also measured by NOAA instruments that were co-located with the University of Houston instruments (Luke et al., 2010a, b). In addition, NO was measured with a Penn State Thermo $42 \mathrm{C} \mathrm{NO}_{\mathrm{x}}$ monitor $(6 \%$ uncertainty) connected to the MOPS data acquisition. The comparison of the MOPS NO measurements with those from NOAA showed good agreement, with a slope of 0.98 and an intercept of $0.15 \mathrm{ppbv}$. This agreement indicates that all the instruments were sampling basically the same air masses despite the slight separation in the measurement inlets for the different species.

Volatile organic compounds $\left(C_{2}-C_{10}\right)$ were measured by University of Houston $(5.4 \%$ and $10.2 \%$ uncertainty for alkanes and alkenes, respectively) with a gas chromatographic system coupled to a flame ionization detector (GCFID) (Leuchner and Rappenglück, 2010). Other organic compounds were measured by Washington State University with a PTR-MS (20\% uncertainty) (Jobson et al., 2005).

Thus, all of the chemical species needed to model and calculate $P\left(\mathrm{O}_{3}\right)$ were measured during SHARP. The specific computations for each case are explained in the following sections. 


\section{2 $P\left(\mathrm{O}_{3}\right)$ from modeled radicals (called modeled $\left.P\left(\mathrm{O}_{3}\right)\right)$}

The modeled concentrations of the radicals $\mathrm{HO}_{2}, \mathrm{RO}_{2}$, and $\mathrm{OH}$ were used in Eqs. (2)-(4) to compute $P\left(\mathrm{O}_{3}\right)$. Radicals came from runs of a box model using RACM2, which is an updated version of RACM (Stockwell et al., 1997). The main updates include new oxidation schemes for isoprene and aromatics (benzene, toluene and xylenes). Some organic species such as acetone, acetaldehyde, and methyl vinyl ketone are treated explicitly. A few new reactions such as the photolysis of benzaldehyde and glyoxal and organic acids $+\mathrm{OH}$ were added. The RACM2 mechanism includes 356 reactions and 117 total species, including 17 stable inorganic species, 4 inorganic intermediates, 54 stable organic species (4 of these are primarily of biogenic origin) and 42 organic intermediates (Goliff and Stockwell, 2008, 2012).

In the present study, measurements of atmospheric constituents and environmental parameters were used to constrain the model. These measurements include $\mathrm{NO}, \mathrm{NO}_{2}$, $\mathrm{SO}_{2}, \mathrm{CO}, \mathrm{O}_{3}$, VOCs $\mathrm{C}_{2}-\mathrm{C}_{10}$, oxygenated hydrocarbons, photolysis rate coefficients, and meteorological data. While NO is constrained by the measured $\mathrm{NO}, \mathrm{HO}_{2}$ is calculated and can be compared to the measured $\mathrm{HO}_{2}$. Modeled $P\left(\mathrm{O}_{3}\right)$ is calculated using modeled values for the radicals in Eq. (4).

The contribution of $\mathrm{RO}_{2}$ radicals to ozone production was computed from individual peroxy radicals calculated in the RACM2 mechanism, i.e., $P\left(\mathrm{O}_{3}\right)_{\mathrm{RO} 2}=\Sigma k_{\mathrm{RO} 2 i+\mathrm{NO}}$. $\left[\mathrm{RO}_{2 i}\right] \cdot[\mathrm{NO}]$, where the approximately twenty $\mathrm{RO}_{2 i}$ species are calculated by the model. The contribution to $P\left(\mathrm{O}_{3}\right)$ from these $\mathrm{RO}_{2}$ radicals is typically 1 to $8 \mathrm{ppbvh}^{-1}$, peaking at noon and is generally about half of the total modeled $P\left(\mathrm{O}_{3}\right)$. The production of nitric acid (first term on the right-hand side of Eq. 3) via reaction of $\mathrm{OH}$ and $\mathrm{NO}_{2}$ typically removes $10 \%$ of the chemical ozone production, $p\left(\mathrm{O}_{3}\right)$. The reaction of $\mathrm{HO}_{2}$ with $\mathrm{O}_{3}$ (second term of Eq. 3) has a smaller impact, less than $1 \%$. The modeled $P\left(\mathrm{O}_{3}\right)$ reported here comes from the net balance as in Eq. (4).

Chen et al. (2010) determined the uncertainty for modeled $P\left(\mathrm{O}_{3}\right)$ at the $1 \sigma$ confidence level with 2006 data in Houston. These uncertainties were calculated for different hours of the day and for different pollution scenarios, following the Monte Carlo method (Carslaw et al., 1999) and include uncertainties in rate coefficients, product yields, and measurements. In this study we use the model uncertainties determined by Chen et al. (2010), which correspond to $58 \%$ at 08:00, $24 \%$ at $12: 00,22 \%$ at $14: 00$ and $81 \%$ at 23:00 CST.

\section{3 $\quad P\left(\mathrm{O}_{3}\right)$ from measured radicals (called calculated $\left.P\left(\mathbf{O}_{3}\right)\right)$}

The instantaneous ozone production was also calculated from the measured radicals $\mathrm{HO}_{2}, \mathrm{OH}, \mathrm{NO}$, and $\mathrm{NO}_{2}$ using Eqs. (2)-(4). $\mathrm{RO}_{2}$ was not measured, so $\mathrm{RO}_{2}$ from the RACM2 model run was used.
A recent laboratory study suggests that the $\mathrm{HO}_{2}$ measurements in some FAGE-type instruments are susceptible to an interference from $\mathrm{RO}_{2}$ species that come from alkenes (Fuchs et al., 2011). A laboratory study showed that GTHOS is also affected by the same interference. Compared to $\mathrm{HO}_{2}$, the yields for $\mathrm{RO}_{2}$ are 0.68 for isoprene, 0.66 for ethene, 0.40 for cyclohexane, and 0.54 for $\alpha$-pinene. The yields from more alkenes and aromatics are still needed, but a yield of $0.60 \pm 0.15$ is consistent with all species that have been measured so far. Measured $\mathrm{HO}_{2}$ was thus corrected by $0.6 \cdot \mathrm{RO}_{2}$ from alkenes + aromatics and then $P\left(\mathrm{O}_{3}\right)$ was calculated in the same way as for the modeled radicals, replacing the modeled $\mathrm{HO}_{2}$ and $\mathrm{OH}$ with measured $\mathrm{HO}_{2}$ and $\mathrm{OH}$.

The absolute uncertainty of the GTHOS measurement of $\mathrm{HO}_{2}$ was determined to be $\pm 32 \%$ at the $2 \sigma$ confidence limit (Faloona et al., 2004). However, this new revelation about the alkene-based $\mathrm{RO}_{2}$ interference increases that uncertainty. Typical midday radical mixing ratios are $18 \mathrm{pptv}$ for measured $\mathrm{HO}_{2}$ and $4 \mathrm{pptv}$ for modeled alkene-based $\mathrm{RO}_{2}$. Using propagation of error, the overall $2 \sigma$ uncertainty of real $\mathrm{HO}_{2}$ is $\pm 35 \%$ for midday conditions. The $2 \sigma$ uncertainty for $P\left(\mathrm{O}_{3}\right)$ calculated from measured $\mathrm{HO}_{2}$ and $\mathrm{OH}$ is slightly higher at an estimate of $\pm 40 \%$, or $\pm 20 \%$ at $1 \sigma$ uncertainty.

\section{Results}

\subsection{Time series of $P\left(\mathrm{O}_{3}\right)$ measurements and calculations}

A time series shows the general behavior of the 10-min calculated, measured, and modeled $P\left(\mathrm{O}_{3}\right)$ and ambient ozone levels during SHARP (Fig. 1). The measured $P\left(\mathrm{O}_{3}\right)$ obtained using the MOPS shows the expected diurnal variations for $P\left(\mathrm{O}_{3}\right)$, although the peak values vary day to day. The MOPS started measuring on 29 April 2009 and measured $P\left(\mathrm{O}_{3}\right)$ on 20 days. Much of the MOPS data loss was due to cloudiness and rain showers, especially in the first half of May. Data gaps in the GTHOS measurements and observations needed for the model reduced to 12 the total number of days with data overlap among the three techniques. The pollution conditions on these 12 days varied enough that statistical analyses can be applied to the comparison of the different methods.

In early May, high northward winds, considerable cloudiness, and morning or afternoon showers suppressed ozone production as well as ozone. With the exception of 4 May, $P\left(\mathrm{O}_{3}\right)$ did not exceed $25 \mathrm{ppbv} \mathrm{h}^{-1}$ and ozone did not exceed 50 ppbv.

More intense pollution episodes occurred later in the study. The meteorological conditions on 4, 19, 20 and 21 May were such that high data quality was obtained with the MOPS. The afternoon temperatures peaked at near $30^{\circ} \mathrm{C}$ and the sky was clear. The wind speed was low in the morning, between $1 \mathrm{~m} \mathrm{~s}^{-1}$ and $4 \mathrm{~m} \mathrm{~s}^{-1}$ blowing from the north 


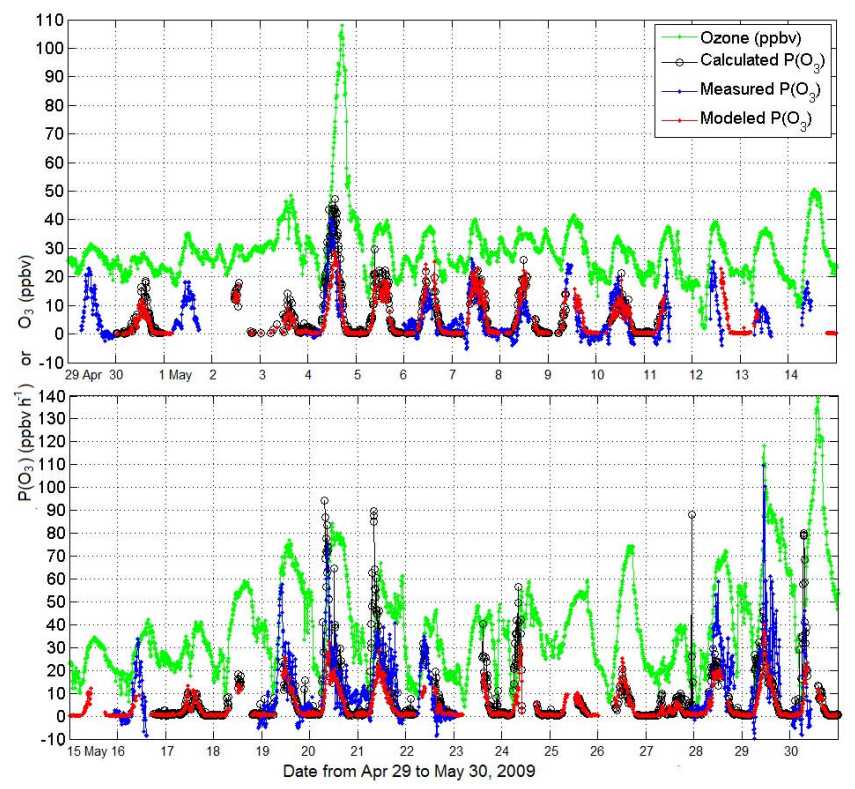

Fig. 1. Time series from 29 April to 30 May 2009 for ambient ozone (green dots), calculated $P\left(\mathrm{O}_{3}\right)$ from measured radicals (black circles), measured $P\left(\mathrm{O}_{3}\right)$ with the MOPS (blue dots) and modeled $P\left(\mathrm{O}_{3}\right)$ from the RACM2 mechanism (red dots).

or northeast directions, and the relative humidity ranged between $30-50 \%$ at noon. These conditions were optimal for ozone formation and accumulation in the air. Additionally, there was low relative humidity during the early mornings and nights. Low humidity minimizes the artifact that affects the MOPS (Cazorla and Brune, 2010) and thus the effects of the known interference due to $\mathrm{NO}_{2}$ loss were negligible. The Texas Commission on Environmental Quality (2011) reported officially that 4,20 and 29 May were pollution events. Ambient ozone on these days surpassed $80 \mathrm{ppbv}$ and the peak $P\left(\mathrm{O}_{3}\right)$ measured with the MOPS was higher than $40 \mathrm{ppbvh}^{-1}$.

There are three anomalies to note in the data set. First, on 29 May the MOPS registered a spike of $110 \mathrm{ppbvh}^{-1}$ for about an hour at 11:00 a.m. that came down below $60 \mathrm{pbbv} \mathrm{h}^{-1}$ in the afternoon. This spike was unique in the MOPS data, for which typical peak $P\left(\mathrm{O}_{3}\right)$ values were in the $40-80 \mathrm{ppbv} \mathrm{h}^{-1}$ range when ozone was high. This spike cannot be explained by any of the other measurements.

Second, on 30 May both the measured and calculated $P\left(\mathrm{O}_{3}\right)$ register a spike of ozone production at 07:00 a.m. The MOPS measured $45 \mathrm{ppb} \mathrm{h}^{-1}$ while the calculation yields about $80 \mathrm{ppbv} \mathrm{h}^{-1}$. This spike is not apparent in the modeled results. On this day, the campaign of measurements for the MOPS ended and afternoon data are not available.

Third, the MOPS measured negative rates of ozone production between 0 and $10 \mathrm{ppbv} \mathrm{h}^{-1}$ in some early mornings and some evenings. One possible explanation is that the removal terms in Eq. (3) are larger than the production terms in Eq. (2). The sample chamber has the radical chemistry to produce nitric acid from $\mathrm{OH}+\mathrm{NO}_{2}$ while the reference chamber does not. The model, however, never shows net $P\left(\mathrm{O}_{3}\right)$ to be negative because if there is sufficient photolysis to produce $\mathrm{OH}$, then there is also sufficient photolysis to form $\mathrm{O}_{3}$ from $\mathrm{NO}_{2}$ that comes from the reaction of radicals and $\mathrm{NO}$ emissions, thus keeping net $P\left(\mathrm{O}_{3}\right)$ positive.

It is more likely that $\mathrm{NO}_{2}$ is preferentially lost in the sample chamber by wall reactions that speed up at higher relative humidities (Wainman et al., 2001). The temperature in the sample chamber was generally found to be less than the temperature in the reference chamber. Hence, the relative humidity would have been greater in the sample chamber than the reference chamber since both had the same absolute water vapor. Experimental evidence suggests that the negative $P\left(\mathrm{O}_{3}\right)$ comes from this wall effect, as explained in Cazorla and Brune (2010).

Despite these few anomalies, the variation in the $P\left(\mathrm{O}_{3}\right)$ measured by the MOPS is qualitatively consistent with the variation in daily peak ozone and with the $P\left(\mathrm{O}_{3}\right)$ calculated with the modeled radicals and the measured radicals. On days when the peak measured $P\left(\mathrm{O}_{3}\right)$ is high, the $\mathrm{O}_{3}$ peak is high later in the day. When the peak measured $P\left(\mathrm{O}_{3}\right)$ is low, the $\mathrm{O}_{3}$ peak is also low. This rough consistency suggests that chemical production of $\mathrm{O}_{3}$ dominates over transport of $\mathrm{O}_{3}$ for this Moody Tower site.

The relationship between measured $\mathrm{O}_{3}$ and $P\left(\mathrm{O}_{3}\right)$ is influenced by both advection and the deposition rate (Eq. 1). Therefore, in Fig. 1, an instantaneous chemical rate of $20 \mathrm{ppbv} \mathrm{h}^{-1}$ is possible even when ambient ozone is low, if $\mathrm{O}_{3}$ is produced locally and then advected away. It is important to recall that the MOPS measures only $P\left(\mathrm{O}_{3}\right)$, the net ambient instantaneous chemical production rate. Likewise, the calculated and modeled $P\left(\mathrm{O}_{3}\right)$ consider only chemical processes. With the ozone budget in mind, when meteorological conditions lead to high ozone days, the production of ozone is the dominant term in the budget equation and the ambient ozone is expected to come from the accumulation of the chemically produced ozone.

\subsection{Comparison between measured, calculated and modeled $\mathrm{P}\left(\mathrm{O}_{3}\right)$}

Measured, calculated and modeled $P\left(\mathrm{O}_{3}\right)$ were compared for overlapping points and only during daylight hours from 05:00 to 20:00 (Fig. 2). Day-to-day variations as well as instrument precision contribute to the scatter in the individual 10 -minute data points. The median diurnal variation $(\mathrm{mdv})$ lines with the estimated $1 \sigma$ error bars provides visual clues for the similarities and differences among the three methods for obtaining $P\left(\mathrm{O}_{3}\right)$.

Between 12:00 and 20:00 the mdv curves for the three sets of data generally have overlapping error bars, indicating that the three methods agree on $P\left(\mathrm{O}_{3}\right)$. From the mdv curves, the modeled $P\left(\mathrm{O}_{3}\right)$ is either lower or greater than measured 


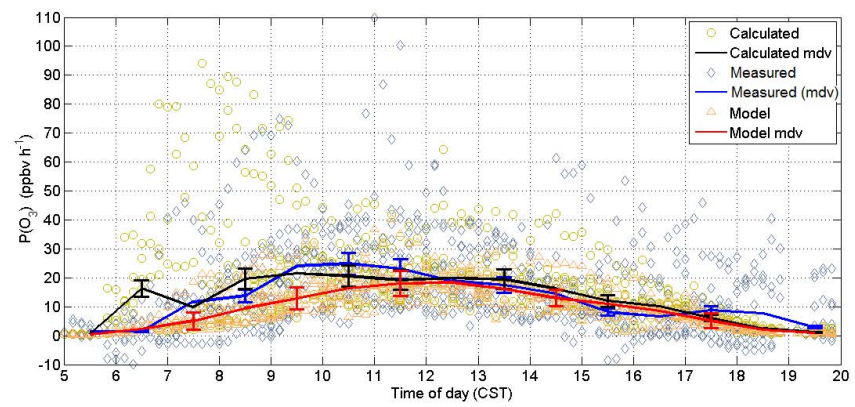

Fig. 2. Overlapping 10-min points and median diurnal variation (mdv) for calculated (yellow circles and black line), measured with the MOPS (light blue diamonds and blue line) and modeled $P\left(\mathrm{O}_{3}\right)$ (orange triangles and red line). Comparison is done for overlapping data only during daylight hours in Central Standard Time (CST). Error bars are $1 \sigma$ based on measurement uncertainty for the GTHOS and MOPS instruments and on calculated model uncertainty at different times of the day.

$P\left(\mathrm{O}_{3}\right)$, whereas the calculated $P\left(\mathrm{O}_{3}\right)$ is always greater than the modeled $P\left(\mathrm{O}_{3}\right)$. In this time period, however, the differences are not statistically significant.

The main differences among the three methods occur in the morning between 05:00 and noon. At 06:30 the calculated $P\left(\mathrm{O}_{3}\right)$ shows a peak of ozone production of $16 \mathrm{ppbvh}^{-1}$ while the levels of measured and modeled $P\left(\mathrm{O}_{3}\right)$ remain below $3 \mathrm{ppbv} \mathrm{h}^{-1}$. This difference comes from the high morning points for calculated $P\left(\mathrm{O}_{3}\right)$ that occurred mainly on 20, 21 and 30 May.

Between 07:00 and noon, the measured and calculated $P\left(\mathrm{O}_{3}\right)$ are generally in agreement and both are about a factor of two greater than the modeled $P\left(\mathrm{O}_{3}\right)$. These differences are marginally statistically significant. In addition, the calculated $P\left(\mathrm{O}_{3}\right)$ tends to be the largest of the three in the early morning between 05:00 and 09:00, while the measured $P\left(\mathrm{O}_{3}\right)$ tends to be largest from 09:00 to 12:00. Thus, the calculated $P\left(\mathrm{O}_{3}\right)$ peaks earliest at 08:00 to 09:00, the measured $P\left(\mathrm{O}_{3}\right)$ peaks next at 10:00 to 11:00, and the modeled $P\left(\mathrm{O}_{3}\right)$ peaks last at 12:00.

A comparison of the median diurnal variation between measured and model $\mathrm{HO}_{\mathrm{x}}$ radicals for the SHARP campaign shows that the ratio of measured to modeled $\mathrm{HO}_{2}$ between 05:00 and 06:00 was about 2; between 06:00 and 07:00 this ratio was $8-10$, just when NO reached its peak at a median value of $4.5 \mathrm{ppbv}$; and then the ratio decreased from about 4 to 2 between 07:00 and noon, while NO decreased from 4 to 0.5 ppbv. Details will be presented in a thorough radical study prepared by Ren et al. (2012). These results are similar to those of Chen et al. (2010) and Mao et al. (2010) for the same site in September 2006. Higher measured-thanmodeled $\mathrm{HO}_{2}$ when $\mathrm{NO}$ is high can explain why the calculated $P\left(\mathrm{O}_{3}\right)$ is high and peaks in the early morning before 07:00. Therefore, differences in the calculated and modeled $P\left(\mathrm{O}_{3}\right)$ are linked to differences between measured and
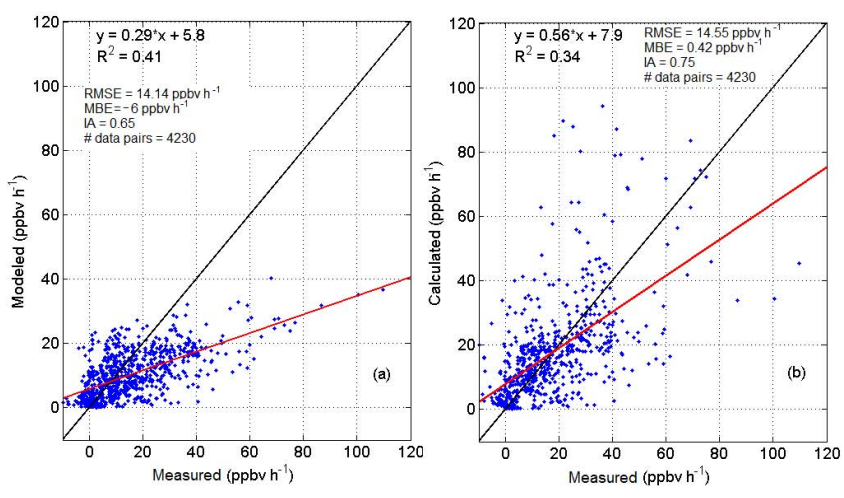

Fig. 3. Scatter plots showing the correlation between (a) modeled and measured $P\left(\mathrm{O}_{3}\right)$ and (b) calculated versus measured $P\left(\mathrm{O}_{3}\right)$. On both plots the black line is the 1:1 line while the red line comes from the linear regression between $y$-axis (calculated or modeled) and $\mathrm{x}$-axis (measured with the MOPS) $P\left(\mathrm{O}_{3}\right)$ values. Errors in slope and intercept are $1.38 \%$ and $32.5 \%$ for (a); and $3.05 \%$ and $71.6 \%$ for (b).

modeled $\mathrm{HO}_{2}$. From a comparison of the median diurnal variation, $P\left(\mathrm{O}_{3}\right)$ from the MOPS measurements agrees with the calculated $P\left(\mathrm{O}_{3}\right)$ to within the estimated uncertainties but is twice the modeled $P\left(\mathrm{O}_{3}\right)$ in the morning.

\subsection{Bias and errors}

The ozone production rates can be subjected to the same kinds of statistical analyses that are used to discuss the performance of air quality models. The linear regressions between modeled and calculated $P\left(\mathrm{O}_{3}\right)$ versus MOPS measurements are shown in Fig. 3a and b, respectively.

The root mean square error (RMSE), mean bias error (MBE) and the index of acceptance (IA) (Willmott, 1981; Appel et al., 2007) have been determined in order to compare each pair of data sets. The RMSE is the average error between model estimations and observations. The MBE contains only the difference between the mean of the model estimations and the mean of the observations. Both RMSE and MBE have the units of the observed or estimated variables. In contrast, the index of agreement is a measurement of the degree of error in model estimations and its values range between 0 and 1, with 1 corresponding to a perfect match.

Eqs. (5) to (7) contain the expressions used to compute these statistical indices.

RMSE $=\sqrt{\frac{\sum_{i}^{N}\left(e_{i}-o_{i}\right)^{2}}{N}}$

$\mathrm{MBE}=\frac{\sum_{i}^{N}\left(e_{i}-o_{i}\right)}{N}$ 


$$
\mathrm{IA}=1-\frac{\sum_{i}^{N}\left(e_{i}-o_{i}\right)^{2}}{\sum_{i}^{N}\left(\left|e_{i}-\bar{o}_{i}\right|+\left|o_{i}-\bar{o}\right|\right)^{2}}
$$

In these equations the $e$ term stands for "estimation", which corresponds either to the modeled or the calculated $P\left(\mathrm{O}_{3}\right)$; the o term represents "observation", which corresponds to the MOPS measurements; and finally, $N$ is the number of data pairs compared. In the present case, $N$ is 4230 for overlapping points among the three sets of data and for daylight hours only between 05:00 and 20:00.

The correlation coefficients $R^{2}$ for the linear regression shown in Fig. 3a and b, are 0.4 for the modeled versus measured $P\left(\mathrm{O}_{3}\right)$ and 0.34 for the calculated versus measured $P\left(\mathrm{O}_{3}\right)$. The slope of the regression, however, is better for the calculated versus measured $P\left(\mathrm{O}_{3}\right)$ with a value of 0.56 as opposed to the modeled versus measured $P\left(\mathrm{O}_{3}\right)$, whose slope is only 0.29 . The error in the slope and intercept in the linear fits are $1.4 \%$ and $33 \%$ for Fig. $3 a$, and $3.0 \%$ and $72 \%$ for Fig. 3b. The index of acceptance is slightly better for the calculated versus measured $P\left(\mathrm{O}_{3}\right)$ at 0.75 than for the modeled versus measured $P\left(\mathrm{O}_{3}\right)$ at 0.65 .

The RMSE was calculated using the 10-min averages of $P\left(\mathrm{O}_{3}\right)$ from measurements and from calculations with measured or modeled radical values. This calculation was done in this way to determine the average error of the two estimated $P\left(\mathrm{O}_{3}\right)$ data sets with respect to the measurements. In both cases the RMSE is comparable, $14.1 \mathrm{ppbv}^{-1}$ for the model and $14.5 \mathrm{ppbv} \mathrm{h}^{-1}$ for the calculation of $P\left(\mathrm{O}_{3}\right)$. This similarity between the RMSE for the calculated and modeled $P\left(\mathrm{O}_{3}\right)$ is misleading because the peak modeled $P\left(\mathrm{O}_{3}\right)$ did not surpass $35 \mathrm{ppbvh}^{-1}$ during high ozone production episodes, while the calculated and measured $P\left(\mathrm{O}_{3}\right)$ show values above $80 \mathrm{ppbv} \mathrm{h}^{-1}$ for the same time period (Fig. 1).

In terms of mean bias error the modeled $P\left(\mathrm{O}_{3}\right)$ has a negative overall bias of $-6 \mathrm{ppbv}^{-1}$ with respect to the MOPS measurements. This result indicates strong underestimation of the predicted modeled values for the majority of the data with respect to the measurements. In contrast, the calculated $P\left(\mathrm{O}_{3}\right)$ has a much lower bias of $0.42 \mathrm{ppbv} \mathrm{h}^{-1}$ with respect to the measurements. This low MBE comes from the closeness in the calculated $P\left(\mathrm{O}_{3}\right)$ to the measured $P\left(\mathrm{O}_{3}\right)$ in particular when the ozone production was high. For such cases, the model had considerably lower values of $P\left(\mathrm{O}_{3}\right)$ with peak values consistently shifted to later in the day.

The MBE and RMSE of the calculated and modeled $P\left(\mathrm{O}_{3}\right)$ versus the measured $P\left(\mathrm{O}_{3}\right)$ vary during the day (Fig. 4a and b). The number of binned pairs of data is indicated on top of the $\mathrm{x}$-axis. For the modeled values, the mean bias is negative for the entire set of data. The largest difference for the modeled $P\left(\mathrm{O}_{3}\right)$ versus measured $P\left(\mathrm{O}_{3}\right)$ occurs between 08:00 and 12:00 when the production of ozone according with MOPS measurements is the largest. The calculated $P\left(\mathrm{O}_{3}\right)$, conversely, is large compared to the measured
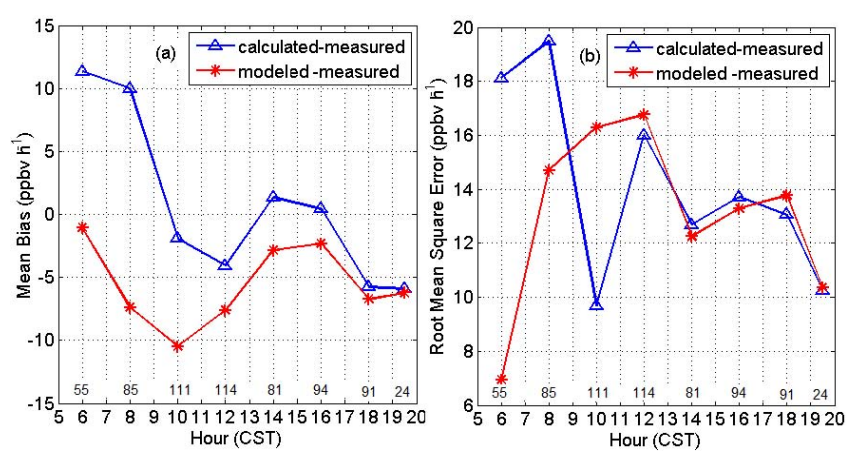

Fig. 4. (a) Mean Bias Error (MBE) and (b) Root Mean Square Error (RMSE) for calculated vs. measured data (blue line and open triangles) and for modeled vs. measured data (red line and stars) binned by hour of the day. The number of binned pairs of data is indicated on top of the $\mathrm{x}$-axis values.

$P\left(\mathrm{O}_{3}\right)$ in the early morning before 09:00, whereas between 10:00 and 16:00, when the data are more abundant, the mean bias fluctuates around 0 .

In similar manner, the RMSE is strongly different between the two methods in the morning until noon. For the modeled values, the RMSE starts low $\left(7 \mathrm{ppbv} \mathrm{h}^{-1}\right)$ at 06:00 and then increases. For the calculated versus measured $P\left(\mathrm{O}_{3}\right)$, the RMSE starts with values higher than $18 \mathrm{ppbv} \mathrm{h}^{-1}$, then the RMSE for the calculated versus measured $P\left(\mathrm{O}_{3}\right)$ generally remains between $10 \mathrm{ppbv} \mathrm{h}^{-1}$ and $14 \mathrm{ppbv} \mathrm{h}^{-1}$.

These MBE's and RMSE's are driven in part by the precision of the measurements as well as by true differences in the methods for determining $P\left(\mathrm{O}_{3}\right)$. Large variations in measured, calculated, and modeled $P\left(\mathrm{O}_{3}\right)$ are clear in Figs. 1 and 2. Thus, part of the MBE and RMSE can be attributed to unknown factors that could be affecting the MOPS measurements, calculated $P\left(\mathrm{O}_{3}\right)$, or modeled $P\left(\mathrm{O}_{3}\right)$. The biases of the calculated and modeled $P\left(\mathrm{O}_{3}\right)$ relative to the measured $P\left(\mathrm{O}_{3}\right)$ are, however, clearly different and reflect differences between these two estimation methods. In total, these statistical analyses provide no clear answer to whether the measured $P\left(\mathrm{O}_{3}\right)$ agrees better with the calculated $P\left(\mathrm{O}_{3}\right)$ or the modeled $P\left(\mathrm{O}_{3}\right)$. Additional field campaign studies are necessary to determine whether the calculated $P\left(\mathrm{O}_{3}\right)$ or the modeled $P\left(\mathrm{O}_{3}\right)$ is correct.

\subsection{Real-time $P\left(\mathrm{O}_{3}\right)$ in NO space}

The evolution of the measured $P\left(\mathrm{O}_{3}\right)$ dependence on NO during the period from 19 May to 21 May is shown in Fig. 5. Since $\mathrm{NO}$ and $\mathrm{NO}_{2}$ are in photosteady state, the shapes of the curves in Fig. 5 look the same even if $P\left(\mathrm{O}_{3}\right)$ is plotted against $\mathrm{NO}_{\mathrm{x}}$ with the $\mathrm{x}$-axis shifted toward larger values of the sum $\mathrm{NO}+\mathrm{NO}_{2}$. Peak $P\left(\mathrm{O}_{3}\right)$ measured with the MOPS reached $60 \mathrm{ppbv} \mathrm{h}^{-1}$ on $19 \mathrm{May}$, a higher value of $75 \mathrm{ppbvh}^{-1}$ on 20 May, and then peaked at a lower value of $40 \mathrm{ppbv} \mathrm{h}^{-1}$ on 21 May. These relative $P\left(\mathrm{O}_{3}\right)$ values are consistent with the relative $\mathrm{O}_{3}$ values for the same days (Fig. 1). 


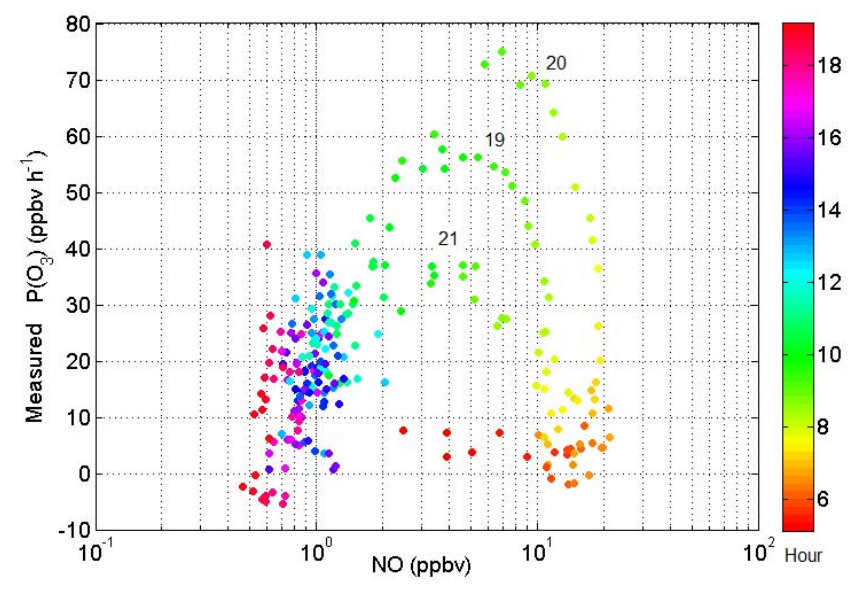

Fig. 5. Measured $P\left(\mathrm{O}_{3}\right)$ in NO space for the high ozone episode that started on 19 May, developed on 20 May and subsided on 21 May 2009 in Houston. The color scale corresponds to hour of the day. The number on top of every curve is the date in May.

The plotted data in Fig. 5 are the individual MOPS data that are recorded every $10 \mathrm{~min}$ without any smoothing or correction. Reading the plots from right to left and using the hour of the day given by the color scale, it is clear that the curves start with high $\mathrm{NO}$ and low $P\left(\mathrm{O}_{3}\right)$ before 08:00, grow rapidly as NO falls past the rush hour, reach broad peaks at around 10:00 when NO ranges between 2-10 ppbv, and finally decrease in the afternoon and evening as NO and other radicals decrease. Note particularly that the peak ozone production occurs at mid to high levels of NO, about 10:00, and that the higher the daily peak $P\left(\mathrm{O}_{3}\right)$ was, the higher $\mathrm{NO}$ for the peak $P\left(\mathrm{O}_{3}\right)$.

A comparison for the measured, calculated, and modeled $P\left(\mathrm{O}_{3}\right)$ as a function of NO is shown in Fig. 6, but only for times when all three methods are available and only for times between 05:00 and 20:00. Not all measured $P\left(\mathrm{O}_{3}\right)$ shown in Fig. 5 appear in Fig. 6 because there were no calculated or modeled $P\left(\mathrm{O}_{3}\right)$ data for some of the measured $P\left(\mathrm{O}_{3}\right)$ data in Fig. 5.

A first observation from Fig. 6 is that modeled $P\left(\mathrm{O}_{3}\right)$ values are low compared to the measured and calculated $P\left(\mathrm{O}_{3}\right)$ for the same hour of the day and the same NO levels. Moreover, there is rough agreement between the measured and calculated $P\left(\mathrm{O}_{3}\right)$ for the magnitude of the peak $P\left(\mathrm{O}_{3}\right)$, although the calculated $P\left(\mathrm{O}_{3}\right)$ has more high values at higher NO levels. In addition, both the calculated and modeled $P\left(\mathrm{O}_{3}\right)$ are close to zero with low scatter for evening hours, whereas the MOPS data are more scattered and include negatives, possibly due to the formation of $\mathrm{HNO}_{3}$ or other artifacts as discussed previously. Thus, while the NO dependence of the MOPS measurement has qualitative similarities with the NO dependence of both the calculated and the modeled $P\left(\mathrm{O}_{3}\right)$, its magnitude is closer to that of the calculated $P\left(\mathrm{O}_{3}\right)$.
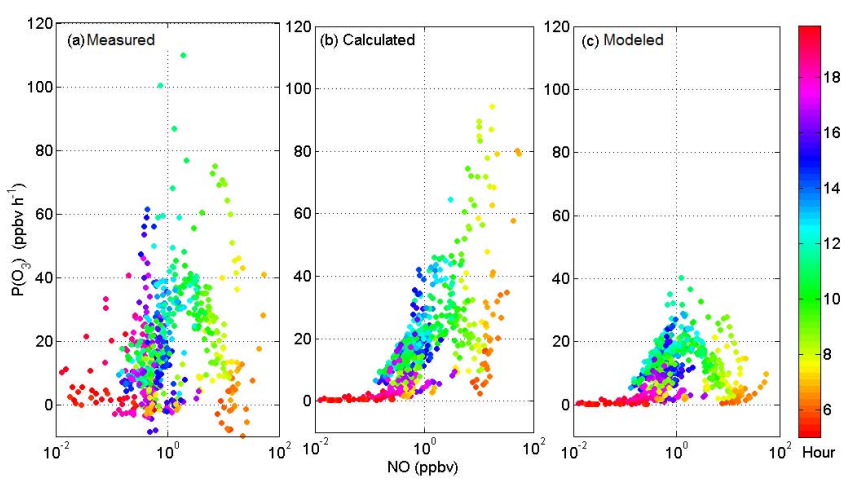

Fig. 6. $P\left(\mathrm{O}_{3}\right)$ in NO space (a) measured by the MOPS, (b) calculated and (c) modeled for overlapping points only and daylight hours. The color scale corresponds to hour of the day.

\section{Conclusions}

The Measurement of Ozone Production Sensor (MOPS) successfully measured the net ozone production rate $P\left(\mathrm{O}_{3}\right)$ during its first field campaign, SHARP, in Houston during April and May 2009. Measured $P\left(\mathrm{O}_{3}\right)$ generally peaked in the mid-to-late morning at values ranging from $20 \mathrm{ppbv} \mathrm{h}^{-1}$ to more than $50 \mathrm{ppbv} \mathrm{h}^{-1}$, with the higher $P\left(\mathrm{O}_{3}\right)$ generally occurring on days with higher ambient $\mathrm{O}_{3}$. When these ozone production rates were integrated over a day, the cumulative ozone was generally greater than the observed ozone, indicating that ozone was being produced locally and then advected elsewhere. Examining this issue in more detail will require another study that compares the MOPS $P\left(\mathrm{O}_{3}\right)$ measurement to an air quality model.

MOPS measurements of $P\left(\mathrm{O}_{3}\right)$ provide a good check on the differences between calculated $P\left(\mathrm{O}_{3}\right)$, which is based on measured $\mathrm{HO}_{2}$ and $\mathrm{OH}$, and modeled $P\left(\mathrm{O}_{3}\right)$, which is based on modeled radicals. The peak measured and calculated $P\left(\mathrm{O}_{3}\right)$ values generally agree and are about twice the modeled values. Further, the measured $P\left(\mathrm{O}_{3}\right)$ peaks in midmorning, later than the calculated $P\left(\mathrm{O}_{3}\right)$ but earlier than the modeled $P\left(\mathrm{O}_{3}\right)$. On the other hand, for $\mathrm{NO}$ greater than about $10 \mathrm{ppbv}$, the measured $P\left(\mathrm{O}_{3}\right)$ is only half of the calculated $P\left(\mathrm{O}_{3}\right)$ but is roughly four times the modeled $P\left(\mathrm{O}_{3}\right)$. The statistical analyses provide mixed evidence that is consistent with these more qualitative comparisons. Some analyses indicate a better agreement between measured and modeled $P\left(\mathrm{O}_{3}\right)$ while other indicate a better agreement between measured and calculated $P\left(\mathrm{O}_{3}\right)$. Hence, it is premature to draw general conclusions from these comparisons, however, some evidence from measured $P\left(\mathrm{O}_{3}\right)$ and $\mathrm{HO}_{2}$ during the SHARP campaign suggest that the modeled $\mathrm{HO}_{2}$ is too low. Providing more conclusive evidence will require greater precision and reduced uncertainties in the MOPS measurements and more observations with the MOPS during intensive field campaigns. Increasing the precision will come from decreasing the statistical noise in the differential ozone sensor. 
Reducing the uncertainties will require more testing of both ozone and radical losses and of ozone production by degassing of $\mathrm{NO}_{\mathrm{x}}$ and VOC products from the chamber walls. Improving the statistics will require more observing with the MOPS. These are all under way.

The deployment of the MOPS during the SHARP field campaign has enabled the first measurements of the direct ambient ozone production rate that have been compared to both modeled and calculated $P\left(\mathrm{O}_{3}\right)$. As more measurements are made in different environments by more groups, and as more laboratory studies of the MOPS are undertaken, it is likely that more will be learned about the strengths and weaknesses of the technique. Issues of calibration and artifacts are likely to emerge, as they have for all previous new measurements. The SHARP data demonstrate the potential of the MOPS. Our ability to verify the calibration and reduce any possible artifacts will determine the value that the MOPS will provide for understanding ozone photochemistry, clarifying the discrepancies between measurements and model $\mathrm{HO}_{2}$, and improving air quality regulations.

Acknowledgements. The authors thank the College of Earth and Mineral Sciences at the Pennsylvania State University for the Miller Faculty Fellowship, which provided graduate student support for M. C. and funds for the fabrication of MOPS. NSF grant ATM-0209972 supported the initial development of MOPS. We also thank J. Flynn, W. Luke, B. Rappenglück, T. Jobson, and others for providing measurements of $\mathrm{NO}_{\mathrm{x}}$ and VOCs used in the modeling.

Edited by: A. Hofzumahaus

\section{References}

Appel, K. W., Gilliland A. B., Sarwar G., and Gilliam, R. C.: Evaluation for the community multiscale air quality (CMAQ) model version 4.5: Sensitivities impacting model performance Part I Ozone, Atmos. Environ., 41, 9603-9615, 2007.

Carslaw, N., Jacobs, P. J., and Pilling, M. J.: Modeling $\mathrm{OH}, \mathrm{HO}_{2}$, and $\mathrm{RO}_{2}$ radicals in the marine boundary layer 2, Mechanism reduction and uncertainty analysis, J. Geophys. Res., 104, 3025730273, 1999.

Cazorla, M. and Brune, W. H.: Measurement of Ozone Production Sensor, Atmos. Meas. Tech., 3, 545-555, doi:10.5194/amt3-545-2010, 2010.

Chen, S., Ren, X., Mao, J., Chen, Z., Brune, W. H., Lefer, B., Rappenglück, B., Flynn, J., Olson, J., and Crawford, J. H.: A comparison of chemical mechanisms based on TRAMP-2006 field data, Atmos. Environ., 44, 4116-4125, 2010.

Faloona, I. C., Tan, D., Lesher, R. L., Hazen, N. L., Frame, C. L., Simpas, J. B., Harder, H., Martinez, M., Di Carlo, P., Ren, X., and Brune, W. H.: A laser induced fluorescence instrument for detecting tropospheric $\mathrm{OH}$ and $\mathrm{HO}_{2}$ : Characteristics and calibration, J. Atmos. Chem., 47, 139-167, 2004.

Finlayson-Pitts, B. J. and Pitts, J. N. Jr.: The chemical basis of air quality: Kinetics and mechanism of photochemical air pollution and application to control strategies, in: Advances in Environ- mental Science and Technology, edited by: Pitts Jr., J. N. and Metcalf, R. L., New York, Wiley-Interscience Publication, 75$162,1977$.

Fox, D. G.: Uncertainty in Air Quality Modeling, Bull. Amer. Meteor. Soc., 65, 27-36, 1984.

Fuchs, H., Bohn, B., Hofzumahaus, A., Holland, F., Lu, K. D., Nehr, S., Rohrer, F., and Wahner, A.: Detection of $\mathrm{HO}_{2}$ by laserinduced fluorescence: calibration and interferences from $\mathrm{RO}_{2}$ radicals, Atmos. Meas. Tech., 4, 1209-1225, doi:10.5194/amt4-1209-2011, 2011.

Gery, M. W., Whitten, G. Z., Killus, J. P., and Dodge, M. C.: A photochemical kinetics mechanism for urban and regional scale computer modeling, J. Geophys. Res., 94, 12925-12956, 1989.

Gilliland, A. B., Hogrefe, C., Pinder, R. W., Godowitch, J. M., Foley, K. L., and Rao, S. T.: Dynamic Evaluation of Regional Air Quality Models: Assessing Changes in $\mathrm{O}_{3}$ Stemming from Changes in Emissions and Meteorology, Atmos. Environ., 42, 5110-5123, 2008.

Goliff, W. S. and Stockwell, W. R.: The Regional Atmospheric Chemistry Mechanism, version 2, an update, International conference on Atmospheric Chemical Mechanisms, University of California, Davis, 2008.

Goliff, W. S. and Stockwell, W. R.: The Regional Atmospheric Chemistry Mechanism, version 2, 1. Description and Evaluation, Atmos. Environ., submitted, 2012.

Haagen-Smit, A. J., Bradley, C. E., and Fox, M. M.: Ozone formation in photochemical oxidation of organic substances, Ind. Eng. Chem., 45, 2086-2089, 1953.

Hard, T. M., O'Brien, R. J., Chan, C. Y., and Mehrabzadeh, A. A.: Tropospheric free radical determination by FAGE, Environ. Sci. Technol., 18, 768-777, 1984.

Ho, W. C., Hartley, W. R., Myers, L., Lin, M. H., Lin, Y. S., Lien, C. H., and Lin, R. S.: Air pollution, weather, and associated risk factors related to asthma prevalence and attack rate, Environ. Res., 104, 402-409, 2007.

Hofzumahaus, A., Roher, F., Lu, K., Bohn, B., Brauers, T., Chang, C-C., Fuchs, H., Holland, F., Kita, K., Kondo, Y., Li, X., Lou, S., Shao, M., Zeng, L., Wahner, A., and Zhang, Y.: Amplified Trace Gas Removal in the Troposphere, Science, 324, 17021704, 2009.

Jeffries, H. E.: An experimental method for measuring the rate of synthesis, destruction, and transport of ozone in the lower atmosphere, E.S.E. Publication No. 285, Ph.D. Thesis, Department of Environmental Science and Engineering, University of North Carolina, Chapel Hill, N.C., 1971.

Jobson, B. T., Alexander, M. L., Maupin, G. D., and Muntean G. G.: On-line analysis of organic compounds in diesel exhaust using a proton transfer reaction mass spectrometer (PTR-MS), Int. J. Mass Spectrom., 245, 78-89, 2005.

Kanaya, Y., Cao, R., Akimoto, H., Fukuda, M., Komazaki, Y., Yokouchi, Y., Koike, M., Tanimoto, H., Takegawa, N., and Kondo, Y.: Urban photochemistry in central Tokyo: 1. Observed and modeled $\mathrm{OH}$ and $\mathrm{HO}_{2}$ radical concentrations during the winter and summer of 2004, J. Geophys. Res., 112, D21312, doi:10.1029/2007JD008670, 2007.

Kleinman, L. I.: The dependence of tropospheric ozone production rate on ozone precursors, Atmos. Environ., 39, 575-586, 2005.

Lefer, B. L., Rappenglück B., Olaguer E. P., Brune, W., Stutz, J., Dibb, J. E., Ren, X., Herndon, S. C., Jobson, T. B., Mount, G., 
Yu, X. Y., Griffin, R., Thomas, S., Shauck, M., Huey, L. G., Zhang, R., and Jimenez, J. L.: First Results of the Study of Houston Atmospheric Radical Precursors (SHARP), 12th Conference on Atmospheric Chemistry, American Meteorological Society, 2010.

Lefer, B., Rappenglu“ck, B., Flynn, J., and Haman, C.: Photochemical and meteorological relationships during the Texas-II Radical and Aerosol Measurement Project (TRAMP), Atmos. Environ, 44, 4005-4013, 2010.

Leuchner, M. and Rappenglück, B.: VOC source-receptor relationships in Houston during TexAQS-II, Atmos. Environ., 44, 40564067, 2010.

Logan, J. A., Prather, M. J., Wofsy, S. C., and McElroy, M. B.: Tropospheric Chemistry: A global perspective, J. Geophys. Res., 86, 7210-7254, 1981.

Luke, W. T., Kelley, P., Lefer, B. L., and Flynn, J. H.: Measurements of reactive nitrogen compounds $\left(\mathrm{NO}, \mathrm{NO}_{X}, \mathrm{NO}_{Y}\right)$ during SHARP, 12th Conference on Atmospheric Chemistry, American Meteorological Society, 2010a.

Luke, W. T., Kelley, P., Lefer, B. L., Flynn, J., Rappenglück, B., Leuchner, M., Dibb, J. E., Ziemba, L. D., Anderson, C. H., and Buhr, M.: Measurements of primary trace gases and $\mathrm{NO}_{y}$ composition in Houston, Texas, Atmos. Environ, 44, 4068-4080, 2010 b.

Madden, M. C. and Hogsett, W. E.: A Historical Overview of the Ozone Exposure Problem, Human Ecol. Risk Assess., 7, 11211131, 2001.

Mao, J., Ren, X., Chen, Z., Brune, W. H., Martinez, M., Harder, H., Lefer, B., Rappenglu“ck, B., and Flynn, J.: Atmospheric oxidation capacity in the summer of Houston 2006: Comparison with Summer Measurements in Other Metropolitan Studies, Atmos. Environ., 44, 4107-4115, 2010.

Martinez, M., Harder, H., Kovacs, T. A., Simpas J. B., Bassis, J., Lesher, R., Brune, W. H., Frost, G. J., Williams, E. J., Stroud, C. A., Jobson, B. T., Roberts, J. M., Hall S., R., Sheter, E., Wert B., Fried A., Alicke B., Stutz, J., Young, V. L., White, A. B., and Zamora, R. J.: $\mathrm{OH}$ and $\mathrm{HO}_{2}$ concentrations, sources, and loss rates during the Southern Oxidants Study in Nashville, Tennessee, summer 1999, J. Geophys. Res., 108, 4617, doi:10.1029/2003JD003551, 2003.

McCarthy, J. E.: Ozone Air Quality Standards: EPA's Proposed January 2010 Revisions, Congressional Research Service, available at: www.fas.org/sgp/crs/misc/R41062.pdf (last access: 20 January 2012), 2010.
National Research Council (NRC), Rethinking the ozone problem in urban and regional air pollution, Natl. Acad. Press, 109-186, 1991.

Ren, X., Harder, H., Martinez, M., Lesher, R., Oliger, A., Simpas, J., Brune, W., Schwab J., Demerjian K., He, Y., Zhou, X., and Gao, $\mathrm{H} .: \mathrm{OH}$ and $\mathrm{HO}_{2}$ Chemistry in the urban atmosphere of New York City, Atmos. Environ., 37, 3639-3651, 2003.

Ren, X., Harder, H., Martinez, M., Faloona, I. C., Tan, D., Lesher, R. L., Di Carlo, P., Simpas, J. B., and Brune, W. H., Interference testing for atmospheric $\mathrm{HO}_{\mathrm{x}}$ measurements by laser-induced fluorescence, J. Atmos. Chem., 47, 169-190, 2004.

Ren, X., Van Duin, D., Cazorla, M., Chen, S., Brune, W. H., Flynn, J. H., Grossberg, N., Lefer, B. L., Rappenglück, B., Wong, K. W., Tsai, C., Stutz, J., Dibb, J. E., Jobson, B. T., Luke, W., and Kelley, P.: Atmospheric oxidation chemistry and ozone production: Results from SHARP 2009 in Houston, Texas, in preparation, 2012.

Seinfeld, J. H. and Pandis, S. N.: Atmospheric chemistry and physics from air pollution to climate change, second edition, Wiley, New Jersey, 204-274, 2006.

Shirley, T. R., Brune, W. H., Ren, X., Mao, J., Lesher, R., Cardenas, B., Volkamer, R., Molina, L. T., Molina, M. J., Lamb, B., Velasco, E., Jobson, T., and Alexander, M.: Atmospheric oxidation in the Mexico City Metropolitan Area (MCMA) during April 2003, Atmos. Chem. Phys., 6, 2753-2765, doi:10.5194/acp-62753-2006, 2006.

Stockwell, W. R., Kirchner, F., and Kuhn, M.: A new mechanism for regional atmospheric chemistry modeling, J. Geophys. Res., 102, 25847-25879, 1997.

Texas Commission On Environmental Quality: 2009 Air Pollution Events, available at: http://www.tceq.state.tx.us/compliance/ monitoring/air/monops/sigevents09.html last access: 20 January 2012), 2011.

United States Environmental Protection Agency (US EPA), National Ambient Air Quality Standards for Ozone (Proposed Rule), Federal Register 75, 11 (January 19, 2010), 2938-3052, available at: http://www.epa.gov/glo/fr/20100119.pdf, 2010.

Wainman, T., Wescheler C. J., Lioy, P. J., and Zhang, J.: Effects of surface type and relative humidity on the production and concentration of nitrous acid in a model indoor environment, Environ. Sci. Technol., 35, 2200-2206, 2001.

Willmott, C. J.: On the validation of models, Phys. Geogr., 2, 184194, 1981. 